\title{
Absence of Juxtaglomerular Cells in the Kidneys of Chondrichthyes and Cyclostomi*
}

\author{
Mikio OgurI**, Mizuho OgaWA*** and Hirofumi SoKABE**** \\ (Received April 30, 1970)
}

In the previous paper ${ }^{1)}$, we ascertained that the juxtaglomerular cells (JG cells) were present in the teleostean kidney. Renin was detected also in the kidneys of this class $^{2)}$. Bohle and Walvig ${ }^{3)}$, Capréol and Sutherland ${ }^{4)}$, and Krisnamurthy and BERN $^{5)}$ reported the presence of JG cells in teleostean kidney, respectively. On the contrary, renin and JG cells could not be detected in chondrichthyean and cyclostome kidneys $^{6)}$. The purpose of this report is to present more of the histological pictures, and to extend the studies into different species. We confirmed the absence of JG cells in chondrichthyean and cyclostome kidneys.

\section{Materials and Methods}

The following species were used. Symbols $(\mathrm{a}-\mathrm{g})$ after individual species indicate the places where the materials were obtained, as detailed below.

Chondrichthyes: Nekozame, Heterodontus japonicus at (b), Oose, Orectolobus japonicus at (a,b), Nurse shark, Glinglymostoma cirratum at (c), Shumokuzame, Sphyrna zygaena at (b), Bonnethead, Sphyrna tiburo at (c), Dochizame, Triakis scyllia at (b, d), Bull shark, Carcharhinus leucas at (c), Blacktip shark, Carcharhinus limbatus at (c), Akaei, Dasyatis akajei at (b, d), Stingray, Dasyatis sabina at (c), and Stingray, Potamotrygon circularis at (e).

Cyclostomi: Japanese lamprey, Entosphenus (=Lampetra) japonicus at (f), and Japanese hag-fish, Paramyxine atami at (g).

The materials were collected at the follwing places: (a) the Fisheries Laboratory in Aichi, Faculty of Agriculture, the University of Tokyo, (b) the Shimoda Marine Biological Station, the Tokyo University of Education, (c) the Cape Haze Marine Laboratory, Sarasota, Florida, U.S.A., (d) the Misaki Marine Biological Station, the University of Tokyo, (e) a side channel of the Amazon River, near Leticia, Colombia, (f) Mogami,

* This investigation was supported by a U.S. Public Health Service Research Grant HE-10338 from the National Heart Institute, and partially by O N R Grant G-00016-63.

** Fisheries Laboratory, Faculty of Agriculture, Nagoya University, Nagoya, Japan (小栗翰郎: 名古屋大学農学部水産学教室)

*** Department of Biology, Saitama University, Urawa, Japan (小川瑞穂：埥玉大学生物学教室)

**** Department of Pharmacology, Toho University School of Medicine, Narashino, Japan (㲘我部 博文：東邦大学医学部薬理学教室) 
Shinano and Ishikari Rivers (the special dealer, Yatume Seiyaku Co., Tokyo), and (g) the Fisherman's Union of Izumozaki, Niigata Prefecture.

ZENKER-formol or HeLLY's fluids were used for fixation of the kidney. The sections were stained with BowIE's method ${ }^{7)}$ which has been used exclusively for staining of JG cells in mammalian kidney.

\section{Results and Discussion}

Careful examination was made on the afferent or efferent arterioles in the kidneys of Chondrichthyes. However, the JG cells could not be detected (Figs. 1-4). BoHLE

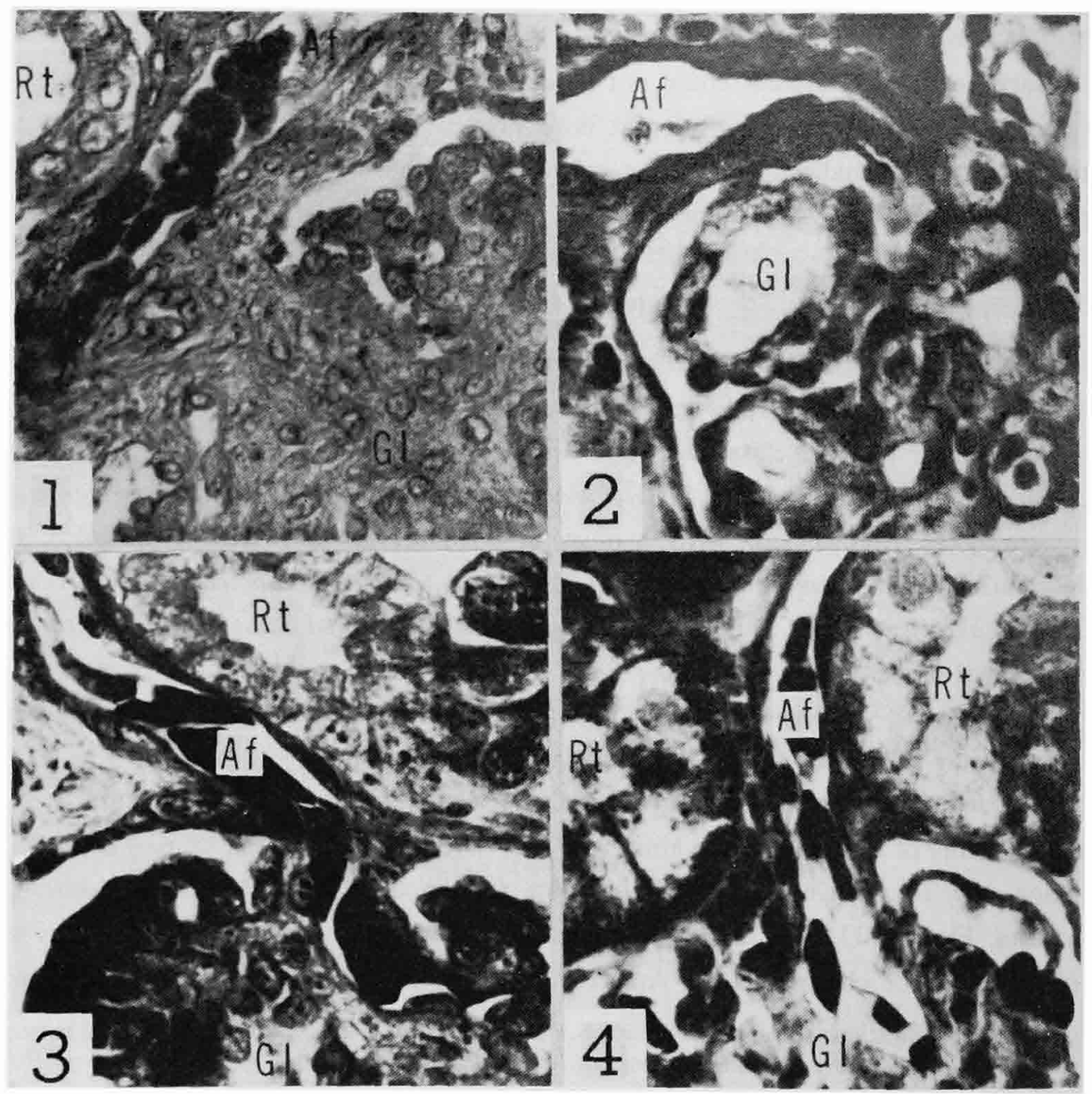

Figs. 1-4. Photographs showing the absence of JG cells in the kidneys of Chondrichthyes.

Fig. 1. Sphyrna tiburo, $\times 917$; Fig. 2, Triakis scyllia, $\times 697$; Fig. 3, Dasyatis akajei, $\times 770$; Fig. 4, Potamotrygon circularis, $\times 800$. BowIE's stain, Af, afferent arteriole; Gl, Glomerulus; Rt, Renal tubule. 
and WALVIG $^{3)}$, and CAPRÉOL and SUTHERLAND ${ }^{4)}$ also could not find the cells in the kidneys of dogfish, Acanthias vulgaris, and barndoor skate, Raja laevis, respectively. Furthermore, NishimuRA et $a l^{6)}$ could not observe renin activity in the kidneys of 4 species of Chondrichthyes, Heterodontus japonicus, Orectolobus japonicus, Triakis scyllia, and Dasyatis akajei. KALEY and his co-workers ${ }^{8)}$ and BEAN $^{9)}$ also reported the absence of renin activity in the kidneys of Chondrichthyes. Accordingly, the kidney of Chondrichthyes seems to be lacking of JG cells.

In the lamprey the glomeruli were fused into a single large glomus measuring $12 \mathrm{~cm}$ in length and $0.33 \mathrm{~mm}$ in width, extending through the dorsal side of the kidney. Since the glomeruli were segmentally supplied by the renal arteries, this long corpuscle seemed to consist of many compartments. Several efferent arterioles can be seen to drain off radially from the glomus within one cross section. It was impossible to identify any JG cells in its afferent arterioles.

In the hag-fish large, oval renal corpuscles (averaging $0.62 \mathrm{~mm}$ in diameter) arranged segmentally on the medial side of an archinephric duct. Each Bowman's capsule was connected to the archinephric duct by a short neck segment having flattened epithelium. The glomeruli were supplied by the branches from the segmental arteries. No JG cells were demonstrable on the afferent arterioles in the kidney.

SUTHERLAND ${ }^{10}$, and CAPRÉOL and SUTHERLAND ${ }^{4)}$ were unable to find JG cells in either the larval or adult lamprey, nor did they find them in the hag-fish. Nishimura et al. ${ }^{\mathbf{6}}$

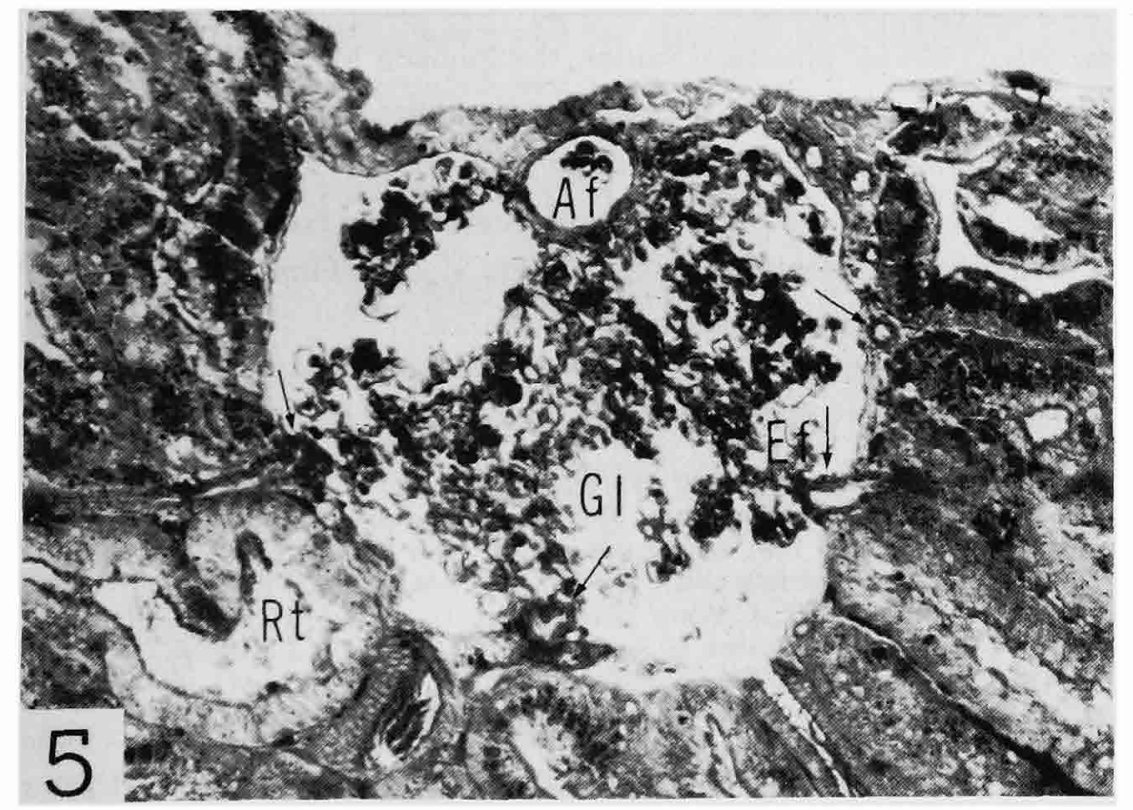

Fig. 5. Photograph showing the absence of JG cells in the kidney of Entosphenus (=Lampetra) japonicus, $\times 170$. BowIE's stain, Af, Afferent arteriole; GI, Glomerulus; Rt, Renal tubule; Ef or $\longrightarrow$, Efferent arteriole. 
could not observe renin activity in their kidneys.

On the other hand, the JG cells are present in the kidneys of teleostean kidneys; BoHLE and WALVIG ${ }^{3 !}$ reported the presence of JG cells in the kidneys of 16 species of teleosts. CAPRÉOL and SUTHERLAND ${ }^{4\}}$ also found the JG cells in the kidneys of 19 species of teleosts. We also detected them in the kidneys of 34 species of teleosts ${ }^{1)}$. Recently, KRISHNAMURTHY and BERN ${ }^{5 /}$ ascertained also the presence of JG cells in 20 species of teleosts. Furthermore, SOKABE and his co-workers ${ }^{2,11,12)}$ confirmed the presence of renin in teleostean kidneys.

Thus, remarkable diffrences were observed between Osteichthyes and more primitive forms, Chondrichthyes and Cyclostomi. This may be related to the different osmoregulatory mechanisms involved in these classes of fishes ${ }^{13}$.

\section{Summary}

Histological examination was made to identify JG cells on the kidneys of eleven species of Chondrichthyes and two species of Cyclostomi. However, the JG cells could not be detected in them.

\section{Acknowledgement}

We wish to thank Dr. Eugenie Clark, Department of Zoology, University of Maryland, and former Director of the Cape Haze Marine Laboratory, Sarasota, Florida, Dr. Thomas B. Thorson, Department of Zoology, University of Nebraska, U.S.A., and staffs of the Misaki Marine Biological Station, the Shimoda Marine Biological Station and the Fisheries Laboratory in Aichi, Faculty of Agriculture, the University of Tokyo, for the facilities they gave us during the collection of materials used in this study. We are also grateful to Prof. T. TAmura, Faculty of Agriculture, Nagoya University, for his kind advices and encouragement throughout the study. Finally, we are indebted to Miss Kiyoko KamiYA for her technical assistance.

\section{References}

1) M. Oguri and H. Sokabe: This Bull., 34, 882-888 (1968).

2) S. Mizogami, M. Oguri, H. Sokabe and H. Nishimura: Am. J. Physiol, 215, $991-994$ (1968).

3) A. Bohle and F. Walvig: Klin. Wochenschr., 42, 415-421 (1964).

4) S. V. Capréol and L. E. Sutherland: Can. J. Zool., 46, 249-256 (1968).

5) V. G. Krishnamurthy and H. A. Bern: Gen. Comp. Endocrinol., 13, 313-335 (1969).

6) H. Nishimura, M. Oguri, M. Ogawa, H. Sokabe and M. Imai: Am. J. Physiol, 218,911-915 (1970).

7) D. J. Bowie: Anat. Rec., 64, 356-367 (1936).

8) G. Kaley, G. A. Robison and B. Lubben: Biol. Bull., 125, 381 (1963).

9) J. W. BeAN: Am. J. Physiol., 136, 731-742 (1942).

10) L. E. Sutherland: Doctoral thesis (1966), cited in Capréol and Sutherland (1968).

11) H. Sokabe, S. Mizogami, T. Murase and F. Sakai: Nature, 212, 952-953 (1966).

12) H. Sokabe, S. Mizogami, and S. Sato: Jap. I. Pharmacol, 18, 332-343 (1968).

13) H. Sokabe, M. Ogawa, M. Oguri and H. Nishimura: Texas Rep. Biol. Med., 27, 867-885 (1969). 